\title{
Lucerne with a high coumestrol content is not a suitable feed for ewes just before and during the early breeding period
}

L.M. CRANSTON ${ }^{1}$, P.R. KENYON ${ }^{1}$, R.L. FIELDS ${ }^{2}$, D.J. MOOT ${ }^{2}$ R.A. CORNER-THOMAS ${ }^{1}$, P.D. KEMP ${ }^{1,3}$ and S.T. MORRIS ${ }^{1}$ ${ }^{I}$ Sheep Research Centre, Institute of Veterinary, Animal and Biomedical Sciences, Massey University, Private Bag 11222, Palmerston North, New Zealand ${ }^{2}$ Field Research Centre, Faculty of Agriculture and Life Sciences, PO Box 85084 Lincoln University 7647, New Zealand ${ }^{3}$ Institute of Agriculture and Environment, Massey University. Private Bag 11222, Palmerston North, New Zealand

L.Cranston@massey.ac.nz

Abstract

The objective was to determine whether grazing lucerne for 7 days before breeding and for the first 7 days of breeding affected the reproductive performance of ewes with different body condition scores (average of 3.2 versus 3.7 ). This was compared with grazing a grass-based sward with a high proportion of dead herbage that was available at the time of breeding in a summer dry region (Wairarapa) in autumn 2016. The lucerne contained large amounts of fungal infected stem and dead herbage, which induced high levels of coumestrol $(107 \pm 15 \mathrm{mg} / \mathrm{kg}$ DM). By the end of the feeding period the grass and lucerne on offer were both of low quality (7.8 MJ ME $/ \mathrm{kg} \mathrm{DM}$ ). Ewes that grazed lucerne for 7 days before breeding and for the first 7 days of the breeding period produced 18 fewer $(\mathrm{P}<0.05)$ foetuses per 100 ewes joined, compared with ewes grazing grass. These findings indicate there was no benefit of grazing ewes on lucerne with a high level of coumestrol under summer drought conditions compared with grazing poor quality grass.

Keywords: alfalfa, coumestrol, drought, flushing nutrition, oestrogen, reproduction

\section{Introduction}

The east coast regions of New Zealand often experience extremely hot, dry conditions during summer and in early autumn. Pastoral systems are predominantly based on temperate grasses (Lolium perenne, Festuca arundinacea, Agrostis capillaris) with different legume components (Trifolium repens, T. pratense, $T$. subterraneum). Under hot, dry conditions, however, grass-based swards have poor growth and quality which limits the feed available for ewes before and during the breeding period.

Lucerne (Medicago sativa) is a perennial forage which produces large yields of high quality dry matter throughout summer and autumn (Douglas 1986) and is used in dryland areas to help balance feed supply in this period. Lucerne has been shown to improve the growth rates of both ewes and lambs throughout summer and autumn and enables increased stocking rates compared o grass-based swards (Douglas 1986; Robertson et al. 1995. Burke et al. 2002). Howeve costrones fungal infection (Loper \& Hanson 1964; Sherwood $e$ al. 1970). Historical data shows grazing lucerne with a high coumestrol content before and during breeding led to reduced ewe ovulation rates, resulting in 10 to $30 \%$ fewer multiple births on lucerne than grass-based swards (Coop \& Clark 1960; Scales et al. 1977; Smith et al. 1979). As a consequence, conservative current advice is for farmers to remove ewes from lucerne 2-3 breeding (Kenyon \& Web may mean that ewes are unable to receive sufficien nutrition to gain liveweight or condition before breeding if they are grazed on poor quality grass-based swards. Conversely, anecdotal evidence suggests some farmers are breeding ewes on lucerne with low levels of coumestrol with positive results.

A recent Australian study, reported merino ewes ( $\sim 60$ $\mathrm{kg}$ with a body condition score (BCS) range of 2.8-3.2) grazed on lucerne for 7 days before breeding and for the first 7 days of the breeding period had 30\% more foetuses and 19\% more lambs docked per ewe than ewes grazing senescent pasture (Robertson et al. 2015) The coumesterol status of the feed was not reported, although the lucerne on offer was mainly green leaf with minimal fungal disease. This result suggests the provision of lucerne had a positive effect on breeding performance. The contradiction in results between to clarify the The aim of the present study was to compare the effects of short-term grazing of lucerne on foetal numbers and the breeding pattern in Romney ewes of medium and high BCS with those fed poor quality grass-based pasture. Previous studies have shown BCS has a genera positive effect on ewe breeding pattern, ovulation rate and number of lambs born, with the general plateauing 
al. 2014). To date there appears to be no data on the potential interaction between lucerne feeding and BCS on ewe reproductive performance.

\section{Materials and methods}

The experiment was undertaken on Riverside farm $11 \mathrm{~km}$ northwest of Masterton $\left(40^{\circ} 50^{\prime} \mathrm{S}, 175^{\circ} 38^{\prime} \mathrm{E}\right)$ between March and July 2016, with the approval of the Massey University Animal Ethics Committee. Before starting the experiment, ewes grazed a grass/white clover (L. perenne/T. repens) sward (hereafter referred to as grass). The site had experienced a wet January ( $85 \mathrm{~mm}$ rain over 9 days), a more typical February ( $\mathrm{mm}$ rain over 4 days) and a drier than normal March 2016 (24 mm rain over 6 days) (NIWA weather station, DO5974). Throughout this time average minimum and maximum temperatures were $12.8^{\circ}$ and $26.8^{\circ} \mathrm{C}$, respectively.

On 8 March 2016 approximately 1000 mixed-age Romney ewes were body condition scored (BCS) on a 1-5 scale (Jefferies 1961). Ewes within two BCS treatment groups were selected; 286 Medium ewes (BCS 2.5 or 3.0, average 2.9), 388 High ewes (BCS 3.5 or 4.0, average 3.8). On 22 March 2016 (Day-10 of breeding), ewes within the two BCS treatment groups were randomly allocated to one of two nutritional treatments; grazed lucerne (cultivar: Runner II) for 7 days before and for the first 7 days of breeding, 7 ars before and for 7 , 7 days of bre ding hen grass for the remainder of the breeding period, or grazed grass throughout the entire breeding period. During the treatment period, the pasture masses were monitored and managed to provide ad libitum intake with minimum post-grazing residuals of $1500 \mathrm{~kg}$ $\mathrm{DM} / \mathrm{ha}$. Ewes allocated to the lucerne treatment wer gradually introduced to the diet by grazing lucerne for increasing increments between 10 and 8 days before breeding started $(2,4$, and 6 hours daily, respectively). The lucerne treatment contained unrestricted access to perennial ryegrass hay and salt blocks throughout the treatment period. However, the lucerne-fed ewes consumed little hay (total of 1-2 conventiona bales) during the treatment period. Each nutritiona treatment by BCS treatment group combination had two replicates. The ewes from the first replicate of both BCS treatments of each nutritional treatment (i.e. one Medium and one High group) were managed as one mob, as were the other replicates. This resulted in a total of four mobs of ewes.

\section{Animal measurements}

Romney rams fitted with crayon harnesses were introduced at a rate of one per mob of $\sim 170$ ewe on Day 0 (1 April 2016, start of breeding period). Crayon marks were recorded on Days 17 and 34 of the experiment. The rams were rotated between mobs on
Day 3 to avoid ram performance effects on pregnancy rate. On Day 7, the ewes were combined into one large mob and grazed grass-based pasture for the remainder of the experiment. The rams were removed after 34 days of joining. All ewes were pregnancy diagnosed using trans-abdominal ultrasound on 12 July 2016. Ewes were diagnosed as non-pregnant, single-, twinor triplet-bearing. The crayon colour marks were used to determine whether ewes conceived during the first (Day 0-17) or the second (Day 18-34) oestous cycirst is cycle. Ten days before breeding and Days 7 and 48 all ewes were weighed unfasted and body condition scored by a single experienced operator.

\section{Herbage measurements}

Herbage mass was measured post-grazing (Day 0 and 7) by taking four $0.1 \mathrm{~m}^{2}$ quadrat cuts at ground level (Frame 1993) per paddock. These samples were washed before oven-drying at $70{ }^{\circ} \mathrm{C}$ to a constant weight. Herbage samples for estimation of the proportion of live and dead in the sward were randomly collected pre-grazing from each paddock, 10 days before and at the start of the sheep breeding period. Four herbage samples were collected by cutting $1 \times 0.1 \mathrm{~m}$ wide strips to ground level within each paddock. The samples were separated into live herbage (stem and leaf separated for lucerne), dead herbage and white clover (grass only treatment) and oven-dried $70^{\circ} \mathrm{C}$ to a constant weight. Grab he

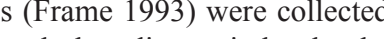
pre-grazing 10 days before the breeding period and at the start by taking four samples per paddock. The samples were freeze-dried and ground to pass a $1 \mathrm{~mm}$ sieve before analysis for in vitro organic matter digestibility (OMD) and dry organic matter digestibility (DOMD) (Roughan \& Holland 1977), crude protein (CP), neutral detergent fibre (NDF) (Robertson \& Van Soest 1981). Metabolisable energy (ME) was calculated as DOMD $\times 0.163$ acording to Rough \& Hollend (1977). At $\times 0.163$ accring to Rout wan \& Hollad (1977). At pamples were also collected (four samples per paddock) for coumestrol analysis. These were oven-dried and a $0.5 \mathrm{~g}$ ground subsample was extracted with $5 \mathrm{ml} \mathrm{99.9 \%} \mathrm{methanol.} \mathrm{Solutions}$ were vortexed for 20 seconds and put on an end over end mixer for 16 hours at room temperature. Samples were centrifuged at $4700 \mathrm{x} g$ and debris removed from supernatant with glass fibre syringe filters. Coumestrol content was meesured by HPLC as described ir et al. (2016).

\section{Statistical analyses}

All data were analysed using SAS (Statistical Analysis System, Version 9.3). Ewe liveweight, liveweight change, BCS and the reproductive performance traits were each analysed using a model including the fixed effects of nutritional treatment, ewe body condition score treatment and their interaction, and the random effect of replicate. Ewe liveweight and liveweight change were analysed using Proc Mixed; BCS was analysed using Proc Glimmix assuming a Poisson distribution; and ewe reproductive performance traits were analysed using Proc Glimmix assuming a binomial distribution. Herbage traits were each analysed using Proc Mixed including the fixed effects of nutritional treatment, sampling date and the random effect of replicate. Data are pres of the mean (SEM).

\section{Results}

\section{Herbage measurements}

Post-grazing herbage mass during the treatment period did not differ $(\mathrm{P}>0.05)$ between the grass treatment and the lucerne treatment $(1618 \pm 226$ and $1558 \pm 226 \mathrm{~kg}$ $\mathrm{DM} /$ ha, respectively). The percentage of live herbage in the sward was affected by an interaction between nutritional treatment and time. Ten days before the treatment (Table 1). During the treatment period the percentage live herbage in the grass treatment increased and the percentage live herbage in the lucerne treatment decreased. However, at the start of the breeding period (Day 0) the lucerne treatment still maintained a higher percentage of live herbage than the grass treatment (Table 1). Within the live herbage of the lucerne respectively.

At Day -10 the lucerne sward had a higher OMD\% and $\mathrm{ME}$ content, and a lower NDF\% than the grass sward (Table 1). However, between Day -10 and Day 0 the $\mathrm{OMD} \%$ and $\mathrm{ME}$ content of the lucerne sward are presented as mean \pm standard error breeding period (Day-10), the lucerne treatment had a higher percentage of live herbage than the grass treatment, the percentage of stem was lower $(\mathrm{P}<0.01)$ on Day -10 than Day 0, 65.7 \pm 5.6 and $76.7 \pm 5.6 \%$,

decreased, and the NDF\% increased so they did not differ from the grass sward at Day 0 (Table 1). The lucerne sward had a higher CP\% compared to the grass sward at both Day -10 and Day 0, however, during the treatment period the $\mathrm{CP} \%$ of the grass sward increased and the $\mathrm{CP} \%$ of the lucerne sward decreased. The lucerne treatment contained an average coumestrol content of $107 \pm 15 \mathrm{mg}$ coumestrol $/ \mathrm{kg}$ DM. The coumestrol/kg DM.

\section{Ewe liveweight and body condition score}

There was no difference $(\mathrm{P}>0.05)$ in the liveweight of ewes allocated to either grass or lucerne at Day -10 (67.7 \pm 0.3 and $67.6 \pm 0.3 \mathrm{~kg}$, respectively). Between Day -10 and Day 7 , the lucerne ewes gained less $(\mathrm{P}<0.01)$ liveweight than the grass ewes $(73 \pm 16.0$ and $102 \pm$ $16.0 \mathrm{~g} /$ day, respectively). However, at Day 48 ewe liveweight did not differ $(\mathrm{P}>0.05)$ among the nutritional treatment groups $(68.5 \pm 0.3$ and $69.0 \pm 0.3 \mathrm{~kg}$ for grass and lucerne ewes, respectively). At Day -10, Medium BCS ewes were lighter $(\mathrm{P}<0.01)$ than High BCS ewes $(64.4 \pm 0.3$ and $71.1 \pm 0.3 \mathrm{~kg}$, respectively) and this liveweight difference remained throughout the study $65.5 \pm 0.3$ and $71.9 \pm 0.3 \mathrm{~kg}$, respectively, at Day 48). There were no interactions between nutritional reatment, BCS treatment and time for ewe liveweight or body condition score ( $\mathrm{P}>0.05$; data not shown).

At Day -10 , there was no difference $(\mathrm{P}>0.05)$ in the BCS of ewes allocated to either grass or lucerne (3.4 $0.1)$. Between Day -10 and 7 , both nutritional treatment groups gained $(\mathrm{P}<0.001)$ similarly in body condition so that the BCS of grass and lucerne treatment ewes did not differ $(\mathrm{P}>0.05)$ at Day 7 (3.6 \pm 0.1$)$. Following the treatment period, all ewes lost body condition $(\mathrm{P}<0.001)$. At Day 48 , the BCS of grass and lucerne

Table 1 Percentage live herbage, crude protein (CP \%), neutral detergent fibre (NDF \%), organic matter digestibility (OMD \%), and metabolisable energy content (MJ ME/kg DM) of lucerne and grass pasture on Day -10 and Day 0 of the breeding
period (mean \pm SEM).

\begin{tabular}{lccccc}
\hline & \% Live herbage & CP (\%) & NDF (\%) & OMD (\%) & ME (MJ/kg DM) \\
\hline Day -10 & & & & & \\
Grass & $1.0 \mathrm{a} \pm 7.0$ & $7.7 \mathrm{a} \pm 0.63$ & $73.1 \mathrm{~b} \pm 3.06$ & $53.3 \mathrm{a} \pm 1.70$ & $7.8 \mathrm{a} \pm 0.24$ \\
Lucerne & $65.2 \mathrm{c} \pm 7.0$ & $18.0 \mathrm{~d} \pm 0.63$ & $45.6 \mathrm{a} \pm 3.06$ & $67.8 \mathrm{~b} \pm 1.70$ & $9.9 \mathrm{~b} \pm 0.24$ \\
\hline Day 0 & & & & & \\
Grass & $8.8 \mathrm{a} \pm 7.0$ & $10.6 \mathrm{~b} \pm 0.63$ & $70.4 \mathrm{~b} \pm 3.06$ & $54.0 \mathrm{a} \pm 1.70$ & $7.9 \mathrm{a} \pm 0.24$ \\
Lucerne & $29.8 \mathrm{~b} \pm 7.0$ & $13.6 \mathrm{c} \pm 0.63$ & $67.6 \mathrm{~b} \pm 3.06$ & $53.8 \mathrm{a} \pm 1.70$ & $7.8 \mathrm{a} \pm 0.24$ \\
\hline P value & & & & & \\
Treatment & $<0.001$ & $<0.001$ & $<0.001$ & $<0.001$ & $<0.001$ \\
Treatment $\times$ Time & $<0.001$ & $<0.001$ & $<0.001$ & $<0.001$ & $<0.001$ \\
\hline
\end{tabular}

Letters indicate values within columns that are significantly different $(P<0,05)$ 
treatment ewes did not differ $(\mathrm{P}>0.05 ; 3.2 \pm 0.1$ and 3.3 \pm 0.1 , respectively)

At Day -10, Medium BCS ewes had a lowe $(\mathrm{P}<0.001)$ BCS than High BCS ewes $(3.2 \pm 0.1$ and $3.7 \pm 0.1$, respectively). Between Day -10 and 7 , both BCS treatment groups gained $(\mathrm{P}=0<001)$ similarly in body condition so that at Day 7 the BCS of the Medium and High BCS treatment groups remained differen $(\mathrm{P}=0<001 ; 3.3 \pm 0.1$ and $3.8 \pm 0.1$, respectively $)$ Following the treatment period, all ewes lost $(\mathrm{P}<0.001)$ similarly in body condition so that at Day 48 the BCS of the Medium and High BCS treatment groups differed $(\mathrm{P}<0.01 ; 3.1 \pm 0.1$ and $3.5 \pm 0.1$, respectively $)$.

\section{Ewe reproductive performance}

Lucerne treatment ewes had a lower proportion of ewes conceiving in the first 17 days of the breeding period and a higher proportion conceiving between days $18-34$, compared to ewes allocated to the grass treatment (Table 2). Lucerne treatment ewes had a higher proportion returning to service than grass treatment ewes. Lucerne treatment ewes had a lower proportion of ewes joined with multiple foetuses and a lower number of foetuses per ewe joined compared to grass treatment ewes. Nutritional treatment had no effect $(\mathrm{P}>0.05)$ on the proportion of non-pregnant ewe $(0.02 \pm 0.007$ and $0.01 \pm 0.007$ for lucerne and grass treatment ewes, respectively).

Ewe BCS treatment had no effect on the pattern of ewes conceiving or the proportion of ewes returning to service (Table 2). However, Medium BCS ewes had a lower proportion of ewes joined with multiple foetuses and a lower number of foetuses per ewe joined compared to High BCS ewes. There was no interaction between nutritional treatment and BCS treatment for any reproductive measure $(\mathrm{P}>0.05$; data not shown).

Table 2 Reproductive performance (mean \pm SEM) of ewes within two BCS treatment groups (Medium and High) allocated to graze a nutritional treatment of either lucerne or grass between Day -7 and Day 7 of the breeding period.

\begin{tabular}{lccccc}
\hline & \multicolumn{2}{c}{$\begin{array}{c}\text { Proportion of ewes } \\
\text { conceiving between }\end{array}$} & $\begin{array}{c}\text { Proportion of ewes } \\
\text { returning to service }\end{array}$ & $\begin{array}{c}\text { Proportion of ewes } \\
\text { joined with multiple } \\
\text { foetuses }\end{array}$ & $\begin{array}{c}\text { Number of foetuses } \\
\text { per ewe joined }\end{array}$ \\
\cline { 2 - 4 } Day 0 - 17 & Day 18 - 34 & & & & \\
\hline Nutritional treatment & & & & & \\
Grass & $0.83 \mathrm{~b} \pm 0.05$ & $0.17 \mathrm{a} \pm 0.05$ & $0.13 \mathrm{a} \pm 0.04$ & $0.77 \mathrm{~b} \pm 0.03$ & $1.88 \mathrm{~b} \pm 0.03$ \\
Lucerne & $0.63 \mathrm{a} \pm 0.07$ & $0.38 \mathrm{~b} \pm 0.07$ & $0.27 \mathrm{~b} \pm 0.07$ & $0.66 \mathrm{a} \pm 0.03$ & $\begin{array}{c}1.70 \mathrm{a} \pm 0.03 \\
<0.001\end{array}$ \\
P-value & $<0.001$ & $<0.001$ & $<0.001$ & $<0.01$ & \\
\hline BCS treatment & & & & & \\
Medium & $0.72 \pm 0.06$ & $0.30 \pm 0.07$ & $0.20 \pm 0.06$ & $0.66 \mathrm{a} \pm 0.03$ & $1.72 \mathrm{a} \pm 0.04$ \\
High & $0.76 \pm 0.05$ & $0.23 \pm 0.06$ & $0.17 \pm 0.05$ & $0.77 \mathrm{~b} \pm 0.03$ & $1.87 \mathrm{~b} \pm 0.03$ \\
P-value & 0.27 & 0.10 & 0.41 & $<0.01$ & $<0.01$ \\
\hline
\end{tabular}

Letters indicate values within columns and parameters that are significantly different $(P<0.05)$. performance in the lucerne treatment ewes, although it is acknowledged that without individual intake data firm conclusions in this regard cannot be made. Based on the data available it seems that the most likely cause of the reduced conception in the present study was due to coumestrol. In contrast, the recent Australian research (King et al. 2010; Robertson et.al. 2015) occurred under conditions of low rainfall and humidity, which are less conducive to fungal infection and thereby minimised the cond the build-up of con explain the difference observed. Therefore, under the conditions of the present study, even with a poor quality grass/clover-based pasture, the results suggest farmers in New Zealand should not graze ewes on lucerne for a short period before and during breeding.

To date in New Zealand, data describing the potential for interaction between lucerne feeding and ewe BCS on reproductive performance are absent. In the present study, ewes of different body condition scores responded in a similar manner when grazing lucerne as when grazing grass, as indicated by a lack of interaction between nutritional treatment and ewe BCS. In support of previous studies, ewes of greater body condition score displayed improved reproductive performance (Kenyon et al. 2014), regardless of nutritional treatment. In the present study, however, the ME content and NDF\% of the lucerne sward was poorer than expected due to a high proportion of stem and dead herbege, and by Day 0 the ME content or $\mathrm{NDF} \%$ of the lucerne did not differ from the grass sward. Therefore, under these conditions it appears there would be no benefit from targeting ewes of differing body condition score (over a range of 2.54.0) for grazing lucerne during the peri-conceptional phase, as the negative impact of the lucerne was consistent across both BCS treatment groups.

\section{ACKNOWLEDGEMENTS}

Catriona Jenkinson, Geoff Purchas and Riverside farm staff are thanked for technical assistance.

\section{REFERENCES}

Burke, J.L.; Waghorn, G.C.; Chaves, A.V. 2002. Improving animal performance using forage-based diets. Proceedings of the New Zealand Society of Animal Production 62: 267-272.

Coop, I.E.; Clark, V.R. 1960. The reproductive performance of ewes mated on lucerne. New Zealand Journal of Agricultural Research 3: 922-933.

Douglas, J.A. 1986. The production and utilization of lucerne in New Zealand. Grass and Forage Science 41: 81-128.

Fields, R.L.; Barrell, G.K.; Moot, D.J. 2016. Premature mammary development in ewe lambs exposed to an oestrogenic lucerne pasture. New Zealand Journal of Grasslands 78: 41-44.
Frame, J. 1993. Herbage Mass. pp. 39-69. In: Sward Measurement Handbook. Eds. Hodgson, J.; Baker, R.; Davies, D.A.; Laidlaw, A.S.; Leaver, J. British Grassland Society, Reading, UK

Jefferies, B.C. 1961. Body condition scoring and its use in management. Tasmanian Journal of Agriculture 32: 19-21.

Kenyon, P.R.; Maloney, S.K.; Blache, D. 2014 Review of sheep body condition score in relation to production characteristics. New Zealand Journal of Agricultural Research 57: 38-64.

Kenyon, P.R.; Webby, R.W. 2007. Pastures and supplements in sheep production systems. p. 54 In: Pasture and Supplements for Grazing Animals Eds. Rattray, P.; Brookes, I.; Nicol, A. New Zealand Society of Animal Production, Hamilton, New Zealand.

King, B.J.; Robertson, S.M.; Wilkins, J.F.; Friend, M.A. 2010. Short-term grazing of lucerne and chicory increases ovulation rate in synchronised Merino ewes. Animal Reproduction Science 121: 242-248.

Loper, G.M.; Hanson, C.H. 1964. Influence of controlled environmental factors and two foliar pathogens on coumestrol in alfalfa. Crop Science 4. 480-482.

Robertson, H.; Niezen, J.; Waghorn, G.; Charleston, W. Jinlong, M. 1995. The effect of six herbages on liveweight gain, wool growth and faecal egg count of parasitised ewe lambs. Proceedings of the New Zealand Society of Animal Production 55: 199-201.

Robertson, J.B.; Van Soest, P.J. 1981. The detergent system of analysis and its application to human foods. pp. 123-158. In: The analysis of dietary fibre in food, Vol. 3. Eds. James, W.; Theander, O. Marcel Dekker Inc., New York, USA.

Robertson, S.M.; Clayton, E.H.; Friend, M.A. 2015. Reproductive performance of ewes grazing lucerne during different periods around mating. Animal Reproduction Science 162: 62-72.

Roughan, P.G.; Holland, R. 1977. Predicting in-vivo digestibilities of herbages by exhaustive enzymic hydrolysis of cell walls. Journal of the Science of Food and Agriculture 28: 1057-1064.

Scales, G.H.; Moss, R.A.; Kelly, R.W. 1977 Reproductive performance of ewes mated on lucerne. Proceedings of the New Zealand Society of Animal Production 37: 152-157.

Sherwood, R. T; Olah, A.F; Oleson, W.H.; Jones, E.E. 1970. Effect of disease and injury on accumulation of a flavonoid estrogen, coumestrol, in alfalfa. Phytopathology 60: 684-688.

Smith, J.F.; Jagusch, K.T.; Brunswick, L.F.C.; Kelly, R.W. 1979. Coumestans in lucerne and ovulation in ewes. New Zealand Journal of Agricultural Research 22: 411-416. 